\title{
PAJAK BERGANDA SECARA EKONOMIS ATAS PENGHASILAN DIVIDEN DI INDONESIA DAN ALTERNATIF PENYELESAIANNYA
}

\author{
Primandita Fitriandi \\ Politeknik Keuangan Negara STAN \\ Benny Setiawan \\ Politeknik Keuangan Negara STAN \\ Arif Widodo \\ Direktorat Jenderal Pajak \\ Alamat Korespondensi: primandita@pknstan.ac.id
}

\section{INFORMASI ARTIKEL}

Diterima Pertama

4 September 2019

Dinyatakan Diterima

23 September 2019

KATA KUNCl:

dividen, pajak berganda, pajak berganda secara ekonomis, kebijakan pajak, investasi

KLASIFIKASI JEL:

$\mathrm{H} 20$

\begin{abstract}
The taxation on income from dividend causes economic double taxation. This happens when profits at the corporate level are taxed and when distributed in the form of dividends to shareholders taxed again. Indonesia still uses a classical tax system that allows this double taxation phenomenon. This research was conducted qualitatively with a case study approach to obtain alternative tax policies on income from dividends. The results demonstrated that several countries have left this system and switched to the dividend exemption tax system or a reduction in tariffs. Therefore, these alternatives can be applied in Indonesia to support a better stock investment climate.
\end{abstract}

\section{ABSTRAK}

Pengenaan pajak pada penghasilan dari dividen menimbulkan pajak berganda secara ekonomis. Hal ini terjadi ketika laba di level perseroan dikenakan pajak dan ketika dibagikan dalam bentuk dividen kepada pemegang saham dikenakan pajak lagi. Indonesia masih menggunakan sistem klasik yang memungkinkan terjadinya fenomena pajak berganda ini. Penelitian ini dilakukan secara kualitatif dengan pendekatan studi kasus untuk mendapatkan alternatif kebijakan pajak atas penghasilan dari dividen. Hasil penelitian menunjukkan bahwa sebagian negara sudah meninggalkan sistem ini dan beralih ke sistem pengecualian dividen sebagai objek pajak atau penurunan tarif. Oleh karena itu, alternatif tersebut bisa diterapkan di Indonesia untuk mendukung iklim investasi saham yang lebih baik. 


\section{PENDAHULUAN}

Investasi dalam bentuk penyertaan saham dalam sebuah perusahaan semakin berkembang dewasa ini. Dibanding investasi konvensional seperti emas, properti, dan obligasi, investasi dalam bentuk saham dianggap lebih menjanjikan meski terkandung risiko yang cukup besar. Selain capital gain, keuntungan selisih beli dan jual, investor juga bisa mendapatkan keuntungan dari dividen yang dimilikinya.

Pasar modal Indonesia yaitu Bursa Efek Indonesia (BEI) termasuk bursa yang menjadi incaran bagi para investor untuk menanamkan modalnya karena kinerjanya yang cemerlang. Presiden Joko Widodo bahkan menyebutkan bahwa kinerja Indeks Harga Saham Gabungan (IHSG) di tahun 2018 adalah yang terbaik di ASEAN dan nomor dua di Asia setelah India. Jumlah investor yang menanamkan saham di BEI semakin meningkat dari tahun ke tahun. Meskipun demikian, jumlah investor saham di Indonesia relatif masih kecil dibanding dengan jumlah penduduk, yaitu sekitar 854 ribu atau sekitar 0,32\% di akhir 2018.

Keuntungan dari bursa selain capital gain adalah dividen. Dividen merupakan distribusi kepada pemegang saham suatu perusahaan secara proporsional dengan jumlah saham yang dimiliki oleh masing-masing pemegang saham (Rudianto, 2012). Dividen yang dibagikan kepada pemegang saham tersebut berasal dari saldo laba ditahan (retained earnings) dari suatu perusahaan. Saldo laba ditahan tersebut merupakan akumulasi dari laba bersih perusahaan yang sebelumnya telah dikenai Pajak Penghasilan sesuai ketentuan yang berlaku.

Sesuai ketentuan perpajakan dividen bisa dibagi menjadi dua, yaitu dividen yang menjadi objek pajak dan bukan objek pajak. Dividen yang menjadi objek pajak adalah yang diterima oleh orang pribadi dalam negeri dan wajib pajak badan atau bentuk usaha tetap yang tidak memenuhi syarat dalam Pasal 4 ayat 3 huruf $f$ Undang-Undang Pajak Penghasilan (UU PPh). Sedangkan dividen yang bukan objek pajak adalah yang diterima oleh wajib pajak badan atau bentuk usaha tetap yang memenuhi syarat dalam Pasal 4 ayat 3 huruf $f$ UU PPh.

Menurut Hutagaol, Darussalam, dan Septriadi (2006), sebagai suatu pajak dari ekuitas (return on equity), maka dapat diartikan bahwa pajak yang dikenakan atas perusahaan atau perseroan berkaitan dengan pajak penghasilan pemegang saham dari perseroan tersebut. Hal ini disebabkan penghasilan perseroan akan menjadi penghasilan (dalam bentuk dividen) bagi pemiliknya. Sehingga apabila atas penghasilan tersebut telah dikenakan pajak di level perseroan kemudian ketika penghasilan diterima oleh pemegang saham sebagai dividen juga dikenakan pajak, maka akan terjadi dua kali pemajakan atas penghasilan yang sama. Fenomena pemajakan atas suatu penghasilan yang sama lebih dari satu kali disebut dengan fenomena pajak berganda secara ekonomis (economic double taxation). Menurut Organisation for Economic Cooperation and Development (OECD): "Double taxation is economic if more than one person is taxed on same item". Lebih lanjut, menurut Darussalam dan Septriadi (2017), pajak berganda secara ekonomis merujuk pada situasi di mana suatu penghasilan yang sama dikenakan pajak lebih dari satu kali di dua atau lebih subjek pajak yang berbeda.

Penelitian ini dimaksudkan untuk menjelaskan fenomena pajak berganda secara ekonomis atas pengenaan pajak terhadap dividen. Dengan menggunakan kajian literatur dan studi kasus, peneliti mengeksplorasi alternatif-alternatif pengenaan pajak atas dividen. Peneliti berharap penelitian ini bisa bermanfaat untuk Direktorat Jenderal Pajak dalam perumusan kebijakan dan memperkaya khazanah pengetahuan untuk akademisi dan praktisi perpajakan.

\section{LANDASAN TEORI DAN PENELITIAN TERDAHULU}

\subsection{Landasan Teori}

Menurut Lazar (2010), terkait dengan upaya untuk mengatasi fenomena pajak berganda secara ekonomis, konsep pemajakan atas laba perusahaan dan juga dividen yang dibagikan kepada pemegang saham yang berlaku di dunia saat ini dapat dibagi menjadi enam kategori, yaitu:

a. Classical System

Konsep classical system ini menyatakan bahwa penghasilan yang bersumber dari perseroan (corporate source income) dikenakan pajak sebanyak dua kali, yaitu pada tingkat perseroan dan juga pada tingkat pemegang dalam bentuk dividen. Dari sisi penerimaan negara, sistem ini akan memberikan dampak penerimaan negara yang cukup besar, namun dari sisi pemegang saham menimbulkan beban pajak yang memberatkan.

b. Modified Classical System

Konsep modified classical system pada dasarnya hampir sama dengan konsep classical, namun perbedaannya terdapat pada tarif pajak atas dividen yang ditetapkan untuk penerima dividen orang pribadi. Tarif tersebut diturunkan agar ketika dihitung jumlah beban pajak efektif tertinggi yang ditanggung pemegang saham orang pribadi akan mendekati tarif pajak penghasilan tertinggi yang dapat dikenakan atas orang pribadi tersebut. Dengan sistem ini, maka untuk pemegang saham orang pribadi penerima dividen yang memang terkena tarif pajak penghasilan tertinggi untuk orang pribadi telah terhindar dari fenomena pajak berganda secara ekonomis. 
c. Full Imputation System

Konsep full imputation system menyatakan bahwa atas laba perusahaan dikenakan pajak di level perusahaan, dan atas dividen yang diterima oleh pemegang saham juga dikenakan pajak. Namun dengan sistem ini, seluruh pajak penghasilan perusahaan yang telah dibayarkan di level perusahaan dapat digunakan sebagai kredit pajak bagi pemegang saham sebagai pengurang dari pajak atas dividen yang diterimanya.

d. Partial Imputation System

Konsep partial imputation system ini sama halnya dengan konsep full imputation, namun bedanya adalah bahwa hanya proporsi tertentu dari pajak penghasilan yang telah dibayarkan di level perusahaan yang dapat digunakan sebagai kredit pajak bagi pemegang saham sebagai pengurang dari pajak atas dividen yang diterima oleh pemegang saham.

e. Total Exemption System

Dengan sistem ini maka seluruh penghasilan dividen yang diterima di level pemegang saham dibebaskan dari pengenaan pajak penghasilan.

f. Partial Exemption System

Dengan sistem ini, maka sebagian penghasilan dividen yang diterima di level pemegang saham dibebaskan dari pengenaan pajak penghasilan.

Sistem perpajakan Indonesia masih menganut classical system. Dengan sistem ini maka pajak penghasilan dikenakan terhadap perseroan dan dividen yang diterima oleh pemegang saham.

\subsection{Dividen}

Dividen adalah proporsi laba atau keuntungan yang dibagikan kepada para pemegang saham dalam jumlah yang sebanding dengan jumlah lembar saham yang dimilikinya (Rudianto, 2012). Pembagian dividen diputuskan melalui Rapat Umum Pemegang Saham (RUPS). Untuk perseroan yang terdaftar di bursa, corporate action berupa pembagian dividen ini diumumkan dalam laman bursa sehingga masyarakat bisa mengetahui jauh-jauh hari dan menentukan tindakan investasinya.

Selanjutnya, Pasal 4 ayat 3 huruf $f$ UU PPh menjelaskan tentang dividen yang bukan objek pajak, yaitu dividen atau bagian laba yang diperoleh atau diterima oleh perseroan terbatas sebagai wajib pajak dalam negeri, koperasi, badan usaha milik negara, atau badan usaha yang didirikan dan bertempat kedudukan di Indonesia dengan syarat:

a. dividen berasal dari cadangan laba yang ditahan; dan

b. bagi perseroan terbatas, badan usaha milik negara, dan badan usaha milik daerah yang menerima dividen, kepemilikan saham pada badan yang memberikan dividen paling rendah dua puluh lima persen dari jumlah modal yang disetor.
Dividen yang diterima oleh wajib pajak badan dalam negeri atau bentuk usaha tetap (BUT) yang tidak memenuhi pasal 4 ayat 3 huruf $f$ UU PPh merupakan objek pajak. Pada saat wajib pajak badan dalam negeri atau BUT tersebut menerima dividen, dilakukan pemotongan Pajak Penghasilan Pasal 23 sebesar $15 \%$ sesuai dengan pasal 23 ayat 1 huruf a angka 1 UU PPh.

Demikian juga, sesuai Peraturan Pemerintah Nomor 19 Tahun 2009 atas dividen yang diterima atau diperoleh oleh orang pribadi dalam negeri dikenai pajak penghasilan sebesar $10 \%$ dan bersifat final. Pemotongan tersebut dilakukan oleh pihak yang membayar atau pihak lain yang ditunjuk selaku pembayar dividen.

\subsection{Konsep Pajak Berganda}

Terdapat pengertian pajak berganda secara yuridis dan pajak berganda secara ekonomis. Menurut Darussalam dan Septriadi (2017), pajak berganda secara yuridis merujuk pada situasi di mana suatu subjek pajak dikenakan pajak oleh lebih dari satu negara atas penghasilan yang sama pada suatu periode yang sama.

Sedangkan, pengertian pajak berganda secara ekonomis (economic double taxation) menurut Organisation for Economic Cooperation and Development (OECD) yaitu: "Double taxation is economic if more than one person is taxed on same item". Menurut Darussalam dan Septriadi (2017), pajak berganda secara ekonomis merujuk pada situasi di mana suatu penghasilan yang sama dikenakan pajak lebih dari satu kali di dua atau lebih subjek pajak yang berbeda.

Berdasarkan pengertian tersebut, terdapat pengenaan pajak berganda secara ekonomis atas penghasilan dividen yang menjadi objek pajak yang diterima oleh orang pribadi dan badan, di mana atas penghasilan dividen tersebut dikenakan pajak berganda, yaitu pada saat berada di level penghasilan kena pajak perusahaan dan pada saat dividen tersebut diterima oleh pemegang saham.

\subsection{Hasil Penelitian Sebelumnya}

Terdapat berbagai penelitian yang telah dilakukan terkait dengan perlakuan perpajakan terhadap dividen yang diterima oleh pemegang saham, yaitu:

a. Ervin L Black, Joseph Legoria, dan Keith F Sellers (Capital Investment Effects of Divident Imputation, 2000) meneliti mengenai dampak dari pemberlakuan dividen imputation pada perhitungan pajak terutang pemegang saham di Australia dan Selandia Baru. Penelitian tersebut menyimpulkan bahwa pemberlakuan dividend imputation memberikan stimulus positif bagi investasi modal di Australia dan di Selandia Baru. 
b. Sebastian Lazar (Double Dividend Taxation Relief: A New View from Corporate Income Tax Perspective, 2010) meneliti tentang pajak berganda atas dividen yang merupakan suatu masalah yang besar di Rumania. Penelitian ini bertujuan untuk mencari alternatif solusi atas fenomena pajak berganda tersebut. Penelitian tersebut menyimpulkan bahwa pengecualian dividen sebagai objek pajak bagi pemegang saham merupakan salah satu alternatif bagi sistem perpajakan di negara tersebut.

c. Robert Carroll, Kevin A. Hassett. dan James B. Mackie III (Effect of Dividend Tax Relief on Investment Incentives, 2003) meneliti mengenai efek dari perlakuan pajak berganda pada penghasilan yang diperoleh perusahaan (pajak atas laba perusahaan dan pajak atas dividen yang diterima oleh pemegang saham). Penelitian tersebut menyimpulkan bahwa perlakuan pajak berganda tersebut menimbulkan efek terhadap Marginal Effective Tax Rates di Amerika Serikat.

\section{METODE PENELITIAN}

Penelitian ini menggunakan metode penelitian kualitatif dengan pendekatan studi kasus. Fokus dalam studi kasus yaitu mengembangkan deskripsi dan analisis mendalam tentang kasus atau beragam kasus (Creswell, 2014). Dalam pengumpulan data peneliti melakukan wawancara dan konfirmasi kepada para informan dan melakukan kajian terhadap teori yang terkait dengan pajak penghasilan atas dividen berupa pembagian laba dari perusahaan kepada pemegang saham.

\section{HASIL PENELITIAN}

\subsection{Perkembangan Peraturan Pajak atas} Penghasilan Dividen di Indonesia

Perkembangan peraturan perpajakan atas penghasilan dari dividen di Indonesia dijelaskan sebagaimana tabel di bawah ini.

\begin{tabular}{|c|c|c|c|}
\hline No & UU & $\begin{array}{c}\text { Perbedaan Kebijakan Pajak atas } \\
\text { Dividen }\end{array}$ & $\begin{array}{l}\text { Tarif } \\
\text { Pajak }\end{array}$ \\
\hline \multirow[t]{2}{*}{1} & \multirow{2}{*}{$\begin{array}{l}\text { UU } \\
\text { Pajak } \\
\text { Dividen } \\
1959\end{array}$} & $\begin{array}{l}\text { Pengenaan pajak atas dividen } \\
\text { bersifat tidak final. }\end{array}$ & $20 \%$ \\
\hline & & $\begin{array}{l}\text { Dividen dikecualikan dari objek } \\
\text { pajak jika dibagikan kepada } \\
\text { negara dan PT, perseroan } \\
\text { komanditer atas saham, } \\
\text { perkumpulan koperasi dan } \\
\text { perkumpulan asuransi gotong- } \\
\text { royong, dan badan lain yang } \\
\text { modalnya seluruhnya atau } \\
\text { sebagian terbagi atas saham } \\
\text { dengan syarat kepemilikan } 25 \% \\
\text { dan kepemilikan saham itu } \\
\text { sudah ada dalam dua belas } \\
\text { bulan terakhir. }\end{array}$ & \\
\hline \multirow[t]{2}{*}{2} & \multirow{2}{*}{$\begin{array}{l}\text { UU } \\
\text { No.7 } \\
\text { Tahun }\end{array}$} & $\begin{array}{l}\text { Pengenaan pajak atas dividen } \\
\text { bersifat final. }\end{array}$ & \\
\hline & & Pengecualian dividen bukan & \\
\hline
\end{tabular}

\begin{tabular}{|c|c|c|c|}
\hline & 1969 & $\begin{array}{l}\text { sebagai objek pajak sama } \\
\text { dengan ketentuan di Undang- } \\
\text { Undang Dividen } 1959\end{array}$ & \\
\hline \multirow[t]{2}{*}{3} & \multirow{2}{*}{$\begin{array}{l}\text { UU } \\
\text { No.7 } \\
\text { Tahun } \\
1983\end{array}$} & $\begin{array}{l}\text { Pengenaan pajak atas dividen } \\
\text { bersifat tidak final. }\end{array}$ & $15 \%$ \\
\hline & & $\begin{array}{l}\text { Dividen dikecualikan dari objek } \\
\text { pajak jika dibagikan kepada } \\
\text { perseroan dalam negeri, selain } \\
\text { bank atau lembaga keuangan } \\
\text { lainnya, dari perseroan lain di } \\
\text { Indonesia (memenuhi syarat } \\
\text { kepemilikan } 25 \% \text { dan kedua } \\
\text { badan tersebut mempunyai } \\
\text { hubungan ekonomis dalam } \\
\text { jalur usahanya) }\end{array}$ & \\
\hline \multirow[t]{2}{*}{4} & \multirow{2}{*}{$\begin{array}{l}\text { UU } \\
\text { No.10 } \\
\text { Tahun } \\
1994\end{array}$} & $\begin{array}{l}\text { Pengenaan pajak atas dividen } \\
\text { bersifat tidak final. }\end{array}$ & $15 \%$ \\
\hline & & $\begin{array}{l}\text { Dividen dikecualikan dari objek } \\
\text { pajak jika diterima atau } \\
\text { diperoleh PT sebagai wajib } \\
\text { pajak dalam negeri, koperasi, } \\
\text { yayasan atau organisasi yang } \\
\text { sejenis, BUMN, atau BUMD dari } \\
\text { penyertaan modal pada badan } \\
\text { usaha yang didirikan dan } \\
\text { bertempat kedudukan di } \\
\text { Indonesia; }\end{array}$ & \\
\hline \multirow[t]{2}{*}{5} & \multirow{2}{*}{$\begin{array}{l}\text { UU } \\
\text { No.17 } \\
\text { Tahun } \\
2000\end{array}$} & $\begin{array}{l}\text { Pengenaan pajak atas dividen } \\
\text { bersifat tidak final. }\end{array}$ & $15 \%$ \\
\hline & & $\begin{array}{l}\text { Dividen dikecualikan dari objek } \\
\text { pajak jika diterima atau } \\
\text { diperoleh PT sebagai Wajib } \\
\text { Pajak dalam negeri, koperasi, } \\
\text { BUMN, atau BUMD (syarat } \\
\text { kepemilikan minimal 25\% dan } \\
\text { harus mempunyai usaha aktif di } \\
\text { luar kepemilikan saham } \\
\text { tersebut) }\end{array}$ & \\
\hline \multirow[t]{2}{*}{6} & \multirow{2}{*}{$\begin{array}{l}\text { UU } \\
\text { No.36 } \\
\text { Tahun } \\
2008\end{array}$} & $\begin{array}{l}\text { Pengenaan pajak atas dividen } \\
\text { bersifat tidak final dan final } \\
\text { (untuk OP DN) }\end{array}$ & $\begin{array}{l}10 \% \\
(\mathrm{OP}) \\
15 \%\end{array}$ \\
\hline & & $\begin{array}{l}\text { Dividen dikecualikan dari objek } \\
\text { pajak jika diterima atau } \\
\text { diperoleh PT sebagai Wajib } \\
\text { Pajak dalam negeri, koperasi, } \\
\text { BUMN, atau BUMD (syarat } \\
\text { kepemilikan minimal } 25 \% \text { untuk } \\
\text { PT, BUMN, BUMD). }\end{array}$ & \\
\hline
\end{tabular}

\subsection{Kebijakan Pajak atas Dividen di Berbagai Negara}

Negara-negara di dunia menganut berbagai macam kebijakan pajak atas penghasilan dividen dari perusahaan atau perseroan yang dibagikan kepada pemegang sahamnya.

Beberapa negara seperti Malaysia dan Singapura telah memberlakukan dividend exemption system berupa one tier tax system dan single tier tax system. Sedangkan Australia telah menerapkan imputation system.

Mulai tahun 2017 Filipina juga telah menerapkan exemption system atas penghasilan dividen yang diterima perusahaan dalam negeri dan 
juga resident foreign corporation dari perusahaan domestik di Filipina. Sedangkan Amerika Serikat masih menerapkan classical system, di mana penghasilan atas dividen masih merupakan objek pajak bagi pemegang saham penerima dividen.

Rangkuman sistem pajak atas penghasilan dividen dari berbagai negara sebagaimana dijelaskan dalam tabel di bawah ini.

a. Australia

Australia menerapkan imputation system sejak bulan Juli tahun 1987. Sistem ini memperbolehkan pajak korporasi yang telah di bayar di level perusahaan untuk digunakan sebagai kredit pajak bagi pemegang saham dari perusahaan ketika pemegang saham menerima dividen dari perusahaan tersebut.

b. Malaysia

Mulai 1 Januari 2008, Malaysia menganut single tier tax system, yaitu sistem perpajakan yang mengecualikan dividen sebagai objek pajak bagi pemegang saham. Berdasarkan single tier tax system, laba bersih dari perusahaan dikenakan pajak pada level perusahaan saja. Ketika laba setelah pajak tersebut didistribusikan kepada pemegang saham sebagai dividen, maka dividen tersebut dikecualikan dari objek pajak.

Sebelum tahun 2008, Malaysia menganut imputation system, yang dilatarbelakangi untuk mengatasi fenomena pajak berganda. Pada tahun 2008 Malaysia beralih menganut single tier tax system dengan tujuan untuk memberikan sebuah sistem yang sederhana, transparan, efisien, dan adil bagi perusahaan, pemegang saham, dan pemerintah (Fatt, 2013).

c. Singapura

Seperti juga di Malaysia, Singapura juga menganut single tier tax system di mana dividen dikecualikan dari objek pajak pada level pemegang saham. Ketentuan ini berlaku sejak tahun 2003 dengan masa transisi selama lima tahun.

d. Filipina

Filipina menganut dividend tax exemption system sejak tahun 2017, dalam sistem ini dividen yang diterima oleh perusahaan dalam negeri Filipina dan resident foreign corporation (perusahaan luar negeri yang mempunyai bisnis di Filipina) yang diterima dari perusahaan dalam negeri bukan merupakan objek pajak.

e. Amerika Serikat

Amerika Serikat masih menganut classical system dalam kebijakan pajak atas dividen, di mana penghasilan dividen merupakan objek pajak ketika penghasilan dividen tersebut diterima oleh pemegang saham baik badan maupun individu. Pada tahun 2003 negara ini mulai menerapkan modified classical system dengan melakukan penurunan tarif pajak atas dividen.

\subsection{Kebijakan atas Penghasilan Dividen yang Berlaku Saat Ini}

Kebijakan pajak yang berlaku saat ini sesuai dengan Undang-undang Nomor 36 Tahun 2008 adalah sebagaimana dijelaskan di bawah ini.

a. Dividen yang Diterima oleh Orang Pribadi Dalam Negeri

Di dalam Undang-Undang Nomor 36 Tahun 2008, penghasilan dividen yang diterima oleh orang pribadi dalam negeri dikenakan tarif final $10 \%$. Tarif ini bersifat final yang berarti pajak atas penghasilan dividen telah berakhir dan tidak lagi diperhitungkan di dalam perhitungan pajak penghasilan tahunan dari orang pribadi tersebut.

Sebelumnya tarif yang dikenakan atas penghasilan dari dividen yang diterima orang pribadi adalah $15 \%$ dan bersifat tidak final. Maksud dari dilakukannya penurunan tarif menjadi $10 \%$ adalah terkait dengan upaya mengurangi dampak negatif dari fenomena pajak berganda secara ekonomis. Selain itu, penurunan tarif ini juga untuk mengurangi beban pajak efektif tertinggi atas laba perusahaan dan dividen yang ditanggung oleh pemegang saham orang pribadi.

Menurut Hutagaol, Darussalam, dan Septriadi (2006), pada dasarnya pajak yang dikenakan pada level perseroan juga menjadi beban bagi pemegang saham karena pajak tersebut akan mengurangi bagian keuntungan (dividen) yang akan diterimanya. Sehingga, dapat dikatakan bahwa atas pajak yang dikenakan di tingkat perseroan juga dirasakan oleh orang pribadi sebagai pemegang saham perseroan.

Perhitungan mengenai beban pajak efektif yang dapat diterima oleh pemegang saham orang pribadi dalam negeri atas penghasilan dividen yang diterima dan juga laba perusahaan di mana pemegang saham tersebut menanamkan sahamnya menurut UU PPh (tarif pajak penghasilan untuk badan $25 \%$, dividen diterima orang pribadi $10 \%$ ) adalah sebagaimana di tabel di bawah ini.

\begin{tabular}{|c|c|}
\hline \multicolumn{2}{|l|}{ Tingkat Perseroan } \\
\hline A. Penghasilan kena pajak & 100 \\
\hline B. PPh badan dalam negeri, tarif $25 \%$ & 25 \\
\hline Laba setelah pajak (A-B) & 75 \\
\hline \multicolumn{2}{|c|}{$\begin{array}{l}\text { Tingkat Pemegang Saham (Jika laba setelah pajak } \\
\text { seluruhnya dibagikan sebagai dividen kepada orang } \\
\text { pribadi dalam negeri) }\end{array}$} \\
\hline C. Dividen & 75 \\
\hline $\begin{array}{l}\text { D. PPh orang pribadi dalam negeri, tarif final } \\
10 \%\end{array}$ & 7,5 \\
\hline \multicolumn{2}{|l|}{ Kombinasi Beban Pajak Penghasilan } \\
\hline E. Total Pajak Penghasilan (B+D) & 32,5 \\
\hline F. Beban Pajak Efektif (E:A) & $32,5 \%$ \\
\hline
\end{tabular}

Berdasarkan simulasi tersebut, orang pribadi dalam negeri penerima dividen dapat memikul beban pajak efektif tertinggi sebesar 32,5\% dari laba 
yang diperoleh perusahaan dan dividen yang diterima oleh orang pribadi tersebut.

b. Dividen yang Diterima oleh Wajib Pajak Badan Dalam Negeri yang Bukan Objek Pajak

Dalam Pasal 4 ayat 3 huruf $f$ UU PPh diatur ketentuan mengenai dividen yang bukan merupakan objek pajak, yaitu dividen atau bagian laba yang diperoleh atau diterima oleh perseroan terbatas sebagai wajib pajak dalam negeri, koperasi, badan usaha milik negara, atau badan usaha milik daerah yang didirikan dan bertempat kedudukan di Indonesia dengan syarat:

- dividen berasal dari cadangan laba yang ditahan; dan

- bagi Perseroan Terbatas, Badan Usaha Milik Negara, dan Badan Usaha Milik Daerah yang menerima dividen, kepemilikan saham pada badan yang memberikan dividen paling rendah $25 \%$ dari jumlah modal yang disetor.

Dengan demikian atas penghasilan dividen yang diterima oleh pemegang saham yang memenuhi ketentuan tersebut, atas penghasilan dividen yang diterima tidak dikenakan pajak lagi. Dalam konsep perpajakan antara perseroan dan pemegang saham, penghasilan dividen yang bukan objek pajak ketika diterima oleh pemegang saham ini disebut dengan dividend exemption system. Filosofi dari pengecualian ini adalah sebagai solusi atas pajak berganda secara ekonomis terhadap pengenaan pajak untuk dividen.

c. Dividen yang Diterima oleh Wajib Pajak Badan Dalam Negeri yang Merupakan Objek Pajak

Dividen yang diterima oleh wajib pajak badan dalam negeri yang tidak memenuhi pasal 4 ayat 3 huruf $f$ Undang-Undang Nomor 36 Tahun 2008 merupakan objek pajak. Pada saat wajib pajak badan dalam negeri menerima dividen, dilakukan pemotongan PPh Pasal 23 sebesar 15\% dan bersifat tidak final. PPh Pasal 23 yang dipotong ini bagi wajib pajak dalam negeri dapat dikreditkan sebagai kredit pajak pada Surat Pemberitahuan (SPT) pajak penghasilan badan di tahun pajak tersebut. Pada saat wajib pajak badan dalam negeri ini melakukan perhitungan pajak penghasilan terutang tahunannya, maka atas penghasilan dividen yang diterimanya juga harus digabungkan dengan penghasilan lain dari wajib pajak badan dalam negeri tersebut dan dikenakan tarif pajak penghasilan yang berlaku untuk wajib pajak badan.

\subsection{Pembahasan Isu Pajak Berganda Secara Ekonomis dalam Pengenaan Pajak atas Dividen di Indonesia}

Dividen merupakan pembagian laba kepada pemegang saham suatu perusahaan. Dividen yang dibagikan kepada pemegang saham tersebut berasal dari saldo laba ditahan (retained earning) dari suatu perusahaan sebagai salah satu bentuk pertanggung jawaban manajemen perusahaan atas pengelolaan perusahaan yang telah dipercayakan oleh pemegang saham sesuai dengan kepentingan pemegang saham. Saldo laba ditahan tersebut merupakan akumulasi dari laba bersih perusahaan yang sebelumnya telah dikenai pajak penghasilan yang berlaku untuk wajib pajak badan. Apabila laba ditahan tersebut dibagikan sebagai dividen kepada pemegang saham, apabila memenuhi kriteria sebagai objek pajak, dividen tersebut akan dikenakan lagi pajak penghasilan.

Berdasarkan hal tersebut, terdapat anggapan mengenai terjadinya fenomena pajak berganda secara ekonomis (economic double taxation) pada pengenaan pajak atas dividen yang diterima oleh pemegang saham karena atas penghasilan dividen tersebut telah dikenakan pajak di level perusahaan. Pajak berganda secara ekonomis merujuk pada situasi di mana suatu penghasilan yang sama dikenakan pajak lebih dari satu kali di dua atau lebih subjek pajak yang berbeda (Darussalam dan Septriadi, 2017). Sedangkan menurut Organisation for Economic Cooperation and Development (OECD): "Double taxation is economic if more than one person is taxed on same item".

Saat ini Indonesia masih menerapkan classical tax system, yaitu menerapkan pengenaan pajak penghasilan atas laba perusahaan di level perusahaan dan dividen yang diterima oleh pemegang saham dikarenakan Indonesia menganggap bahwa antara perusahaan dan pemegang saham adalah dua entitas yang berbeda (separate entity approach). Beberapa negara sudah melakukan upaya untuk menerapkan modern tax system dalam upaya menghilangkan pajak berganda secara ekonomis, baik berupa imputation system atau exemption system. Negara-negara tersebut diantaranya Australia, Selandia Baru, Malaysia, dan Singapura.

\subsection{Alternatif Kebijakan Pajak atas Dividen Yang Dapat Diterapkan di Indonesia}

Alternatif kebijakan pajak atas penghasilan dividen yang dapat diterapkan di Indonesia antara lain sebagai berikut:
a. Dividen Dikecualikan dari Objek Pajak Penghasilan

Menurut Lazar (2010), pengecualian dividen sebagai objek pajak pada saat dividen tersebut diterima oleh pemegang saham merupakan salah satu alternatif bagi permasalahan pajak berganda secara ekonomis. Dengan adanya pemberlakuan dividend exemption system, yaitu sistem yang mengecualikan dividen sebagai objek pajak ketika dividen tersebut diterima oleh pemegang saham, baik wajib pajak badan maupun orang pribadi, maka diharapkan investasi di bursa saham dapat berkembang dengan lebih baik, tidak terkecuali investasi asing.

Terjadinya fenomena pajak berganda secara ekonomis dipandang akan mengurangi minat 
masyarakat untuk melakukan investasi. Sebaliknya penghapusan pajak dividen dinilai akan mendorong investor, khususnya investor lokal, untuk berinvestasi di pasar saham dan sejalan dengan visi $\mathrm{BEI}$ yang tengah menggalakkan program "Yuk Nabung Saham".

Selain itu, penerimaan PPh Pasal 23 atas dividen dan penerimaan pajak final atas dividen selama lima tahun terakhir ternyata relatif kecil dibandingkan penerimaan pajak penghasilan secara keseluruhan sebagaimana terlihat dalam tabel di bawah ini.

(triliun rupiah)

\begin{tabular}{|l|r|r|r|r|}
\hline \multirow{2}{*}{$\begin{array}{c}\text { Penerimaan Per } \\
\text { Jenis Pajak }\end{array}$} & \multicolumn{4}{|c|}{ Tahun } \\
\cline { 2 - 5 } & $\mathbf{2 0 1 5}$ & $\mathbf{2 0 1 6}$ & \multicolumn{1}{c|}{$\mathbf{2 0 1 7}$} & $\mathbf{2 0 1 8}$ \\
\hline PPh 23 dividen & 1.94 & 2.09 & 2.67 & 3.47 \\
\hline PPh final dividen & 3.16 & 3.28 & 4.91 & 5.98 \\
\hline Total PPh Pasal 23 & 27.88 & 29.14 & 34.01 & 39.74 \\
\hline Total PPh final & 119.67 & 106.31 & 117.68 & 115.48 \\
\hline Total PPh & 602.31 & 666.21 & 646.79 & 685.28 \\
\hline $\begin{array}{l}\text { Persentase PPh } \\
\text { dividen terhadap } \\
\text { total PPh }\end{array}$ & $0.85 \%$ & $0.81 \%$ & $1.17 \%$ & $1.38 \%$ \\
\hline
\end{tabular}

Sumber: Direktorat Jenderal Pajak

Berdasarkan data penerimaan tersebut, dapat diketahui bahwa selama tahun 2015 sampai dengan tahun 2018, persentase penerimaan PPh Pasal 23 dan PPh final atas dividen dibandingkan dengan total penerimaan PPh hanya berada di kisaran $1 \%$. Data tersebut dapat dijadikan pertimbangan bagi pemerintah untuk menerapkan alternatif kebijakan pajak berupa pembebasan pajak atas dividen pada saat diterima oleh pemegang saham.

b. Penurunan Tarif Pajak Penghasilan atas Dividen yang Diterima oleh Orang Pribadi Dalam Negeri

Pemerintah telah menurunkan tarif PPh atas dividen yang diterima orang pribadi dalam negeri menjadi $10 \%$. Perubahan tarif ini merupakan upaya yang dilakukan pemerintah untuk mengurangi efek negatif dari fenomena pajak berganda secara ekonomis. Meskipun demikian, pengenaan tarif sebesar $10 \%$ tetap memberi beban pajak efektif yang ditanggung menjadi $32,5 \%$ atau masih lebih tinggi dibanding tarif pajak tertinggi untuk orang pribadi yang $30 \%$.

Oleh sebab itu, alternatif yang dapat dilakukan atas kebijakan pajak atas dividen saat ini adalah dengan penurunan tarif pajak penghasilan atas dividen menjadi lebih kecil dari $10 \%$. Besarnya tarif pajak penghasilan final ini diturunkan ke angka di mana beban pajak efektif tertinggi yang dapat ditanggung oleh orang pribadi pemegang saham atas laba perusahaan dan penghasilan dividen yang diterimanya menjadi sebesar tarif progresif tertinggi dari pajak penghasilan yang berlaku untuk pemegang saham orang pribadi yaitu $30 \%$. Hal ini sesuai dengan konsep pengenaan pajak atas dividen sesuai metode modified classical system menurut Lazar (2010).

Agar beban pajak efektif tertinggi yang dapat ditanggung oleh orang pribadi pemegang saham atas laba perusahaan dan penghasilan dividen yang diterimanya menjadi $30 \%$, maka besarnya tarif pajak atas dividen adalah sebesar maksimal sebesar $6,67 \%$ sebagaimana dijelaskan dalam tabel di bawah ini.

\begin{tabular}{|l|r|}
\hline \multicolumn{2}{|l|}{ Tingkat Perseroan } \\
\hline A. Penghasilan kena pajak & 100 \\
\hline B. PPh badan dalam negeri, tarif 25\% & 25 \\
\hline Laba setelah pajak (A-B) & 75 \\
\hline \multicolumn{2}{|l|}{$\begin{array}{l}\text { Tingkat Pemegang Saham (Jika laba setelah pajak } \\
\text { seluruhnya dibagikan sebagai dividen kepada orang } \\
\text { pribadi dalam negeri) }\end{array}$} \\
\hline C. Dividen & 75 \\
\hline $\begin{array}{l}\text { D. PPh orang pribadi dalam negeri, tarif final } \\
\text { 6,67\% }\end{array}$ & 5 \\
\hline Kombinasi Beban Pajak Penghasilan & 30 \\
\hline E. Total Pajak Penghasilan (B+D) & $30 \%$ \\
\hline F. Beban Pajak Efektif (E:A) & \\
\hline
\end{tabular}

Selain itu, dengan pertimbangan tidak semua orang pribadi dalam negeri memperoleh penghasilan sampai dengan tarif pajak progresif tertinggi sebesar $30 \%$, yaitu penghasilan kena pajak lebih dari 500 juta rupiah, maka tarif PPh atas dividen ini bisa ditetapkan lebih rendah dari 6,67\%, misalnya berkisar antara 3-5\%.

\section{SIMPULAN DAN SARAN}

\subsection{Simpulan}

Pengenaan Pajak Penghasilan atas dividen mengakibatkan terjadinya pajak berganda secara ekonomis (economic double taxation) karena pajak dikenakan pada level perseroan dan pemegang saham saat menerima dividen tersebut. Hal ini dikarenakan pemerintah menganggap perseroan dan pemegang saham merupakan entitas yang berbeda (separate entity).

Pemerintah sudah berupaya mengurangi dampak negatif dari pajak berganda ini dengan cara menurunkan tarif yang semula $15 \%$ menjadi $10 \%$ dan bersifat final untuk dividen yang diterima orang pribadi dalam negeri. Selain itu, dividen yang diterima oleh wajib pajak badan dalam negeri yang memenuhi pasal 4 ayat 3 huruf $f$ UU PPh juga ditetapkan sebagai bukan objek pajak.

Salah satu kebijakan yang bisa diambil untuk menghindari terjadinya pajak berganda secara ekonomis adalah pengecualian dividen sebagai objek pajak penghasilan (dividend exemption system). Sistem ini telah diterapkan di Singapura dan Malaysia.

Selain itu, alternatif lain yang bisa digunakan untuk mengurangi dampak dari pajak berganda 
secara ekonomis adalah penurunan tarif pajak penghasilan atas dividen yang diterima oleh orang pribadi dalam negeri (modified classical system). Tujuan dari penurunan tarif ini adalah untuk menjadikan besarnya beban pajak efektif tertinggi yang ditanggung oleh orang pribadi atas laba perusahaan yang telah dikenakan pajak dan atas penghasilan dividen yang juga dikenakan pajak pada saat diterima adalah sama dengan tarif progresif tertinggi pajak penghasilan yang berlaku untuk orang pribadi dalam negeri. Berdasarkan perhitungan yang dilakukan, penurunan tarif pajak penghasilan final atas dividen tersebut dapat diturunkan hingga menjadi bertarif 6,67\%.

\subsection{Saran}

Upaya yang bisa dilakukan oleh Direktorat Jenderal Pajak untuk mengurangi dampak pajak berganda secara ekonomis antara lain:

a. menerapkan dividend exemption system berupa pengecualian dividen dari pengenaan pajak penghasilan atau modified classical system berupa penurunan tarif pajak penghasilan atas dividen yang diterima orang pribadi dalam negeri seperti yang telah diterapkan oleh negara-negara lain untuk mendukung iklim investasi pasar modal yang lebih baik; dan

b. melakukan kajian lebih mendalam terkait alternatif pengenaan pajak atas dividen dalam hubungannya dengan penerimaan negara dan investasi di pasar modal.

\subsection{Keterbatasan Penelitian}

Penelitian ini tidak terlepas dari berbagai keterbatasan. Keterbatasan dalam penelitian ini antara lain adalah simulasi penelitian ini hanya menggunakan perhitungan sederhana sehingga tidak dapat menggambarkan secara keseluruhan dampak sebenarnya dari penerapan alternatif kebijakan pajak atas penghasilan dividen di Indonesia.

\section{DAFTAR PUSTAKA}

Ainsworth, A. 2016. Dividend Imputation: International Experience. University Of Sydney Business School.

Amans, P.S. 2017. Tax Policy Reforms 2017 Organisation For Economic Co-Operation And Development (OECD) and Selected Partner Economies.

Anderson, James E. 1979. Public Policy Making. Newyork: Holt, Renehart and Wisto.

Aritonang, J. M. 2008. Perpajakan Internasional: Sebagai Materi Studi Di Perguruan Tinggi. Jakarta: Cikal Sakti.

Barton, G.A. 2008. Australian Dividend Withholding Tax. Revenue Law Journal.

Black, E.L, Legoria J, Sellers K.F, 2000. Capital Investment Effects of Dividend Imputation.
Carrol, R., Hasset K.A., Mackie III, J.B., 2003. Effect of Divident Tax Relief on Investment Incentives.

Creswell, John W. Penerjemah Ahmad Lintang Lazuardi. 2014. Penelitian Kualitatif dan Desain Riset, Memilih di Antara Lima Pendekatan. Yogyakarta: Pustaka Pelajar.

Darussalam dan Danny Septriadi. 2017. Perjanjian Penghindaran Pajak Berganda: Panduan, Interpretasi, dan Aplikasi. Jakarta: Penerbit DDTC.

Deloitte. 2017. International Tax Singapore Highlights2017.

Deloitte. 2017. International Tax Malaysia Highlights 2017.

Deloitte. 2016. Taxation and Investment in Singapore 2016 Reach, relevance and reliability.

Dye, Thomas R. 1985. Understanding Public Policy. EnglemoodCliffs N.J.: Prentice Hall,Inc.

Fatt, Choong Kwai. 2008. From a Dividend Imputation System to a Single Tier Dividend System.

Hill, J. 2016. Australia Tax Country Highlight. Deloitte.

Hutagaol, John, Darussalam, dan Danny Septriadi. 2006. Kapita Selekta Perpajakan. Jakarta: Salemba Empat.

Jensen, Michael C., William H Meckling. 1976. ory of Firm: Managerial Behaviour, Agency Cost, and Ownership Structure. NY: University of Rochester.

KPMG. 2015. Singapore Tax Profile, Produced in conjunction with KPMG Asia Pacific Tax Centre.

Lazar, S., 2010. Double Dividend Taxation Relief: A New View From Corporate Income Tax Perspective.

Mansury, R. 2000. Pembahasan Mendalam Atas Pajak Penghasilan. Jakarta: Yayasan Pengembangan dan Penyebaran Pengetahuan Perpajakan.

Mansury. 1992. Indonesian Income Tax, A Case Study in Tax Reform of A Developing Country. Singapore: Asian-Pacific Tax and Investment Research Center.

OECD. 2017. Update To Organisation For Economic Co-Operation And Development (OECD) Model Tax Convention.

Perrin, Robert G. 2014. Functional ory of Change Revisited. US: Univesity of California Press.

PricewaterhouseCoopers. 2018. Worldwide Tax Summaries: Corporate Tax 2017/2018.

Rosdiana, Haula dan Edi Slamet Irianto. 2014. Pengantar Ilmu Pajak: Kebijakan dan Implementasi di Indonesia. Jakarta: Rajawali Pers.

SA Wahab. 1991. Analisis Kebijakan dari Formulasi ke Implementasi Kebijakan Negara. Jakarta: Bumi Aksara. 
Selamat, A., Arif, M., Mohamad, S. 2013. Introduction of Single Tier Corporate Tax System Its Effect on Share Price.

SU, Humaidi. 1993. Mengenal Ilmu Kebijakan Publik. Jakarta: Garoeda Buana Indah.

Sugiyono. 2016. Metode Penelitian Bisnis (Pendekatan Kuantitatif, Kualitatif, dan R\&D. Bandung: Alfabeta.

Surahmat, Rachmanto. 2000. Persetujuan Penghindaran Pajak Berganda: Suatu Pengantar. Jakarta: Gramedia.

Yoingco, A.Q., Recente, M.A., 2003. Is re Double Taxation in Philippine Tax System?

Pemerintah Republik Indonesia. (2008). Undangundang Nomor 7 tahun 1983 tentang Pajak Penghasilan sebagaimana telah diubah terakhir dengan Undang-Undang Nomor 36 Tahun 2008 beserta peraturan pelaksanaannya.

Pemerintah Republik Indonesia. (2007). UndangUndang Nomor 6 tahun 1983 tentang Ketentuan Umum dan Tata Cara Perpajakan sebagaimana telah diubah terakhir dengan Undang-Undang Nomor 28 Tahun 2007 beserta peraturan pelaksanaannya.

Kementerian Keuangan. Laporan Keuangan Pemerintah Pusat Tahun 2012 - 2017.

Inland Revenue Authority of Singapore (IRAS). 2004. Simplification of Income Tax Rules and Procedure

Hidayat, Nurul. 28 Desember 2018. Menjadi Terbaik Kedua di Asia ini Pencapaian Kinerja IHSG Sepanjang 2018. https://market.bisnis.com/ read/20181228/7/873713/menjadi-terbaikkedua-di-asia-ini-pencapaian-kinerja-ihsgsepanjang-2018 